\title{
Pedunculated mobile aortic arch thrombus as a cause for acute stroke
}

\author{
Alexander Marcus Dashwood
}

Department of Cardiology, Gold Coast University Hospital, Southport, Queensland, Australia

\section{Correspondence to} Dr Alexander Marcus Dashwood, icuris247@googlemail.com

Accepted 14 October 2015
CrossMark

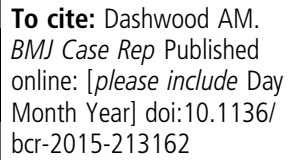

\section{DESCRIPTION}

A 69-year-old man presented with sudden-onset dysphasia and right hemiparesis. MRI of the brain revealed an acute left frontoparietal infarct (figure 1). Carotid Dopplers were normal and ECG showed sinus rhythm. Transthoracic echocardiogram (TTE) revealed a highly mobile $1.33 \mathrm{~cm}$ echogenic mass attached to the superior surface of the aortic arch (figure 2). Subsequent transoesophageal echocardiogram (TOE) did not identify a left atrial appendage thrombus or patent foramen ovale. The patient was started on intravenous heparin prior to warfarin. Given the high-risk nature of the procedure and patient preference, peripheral embolectomy was not pursued. Repeat TTE revealed almost complete resolution at week 6 with no further acute events.

Although extremely rare, aortic arch thrombi are recognised as a cause of systemic emboli. The wall opposite the ostia of the aortic arch has the highest

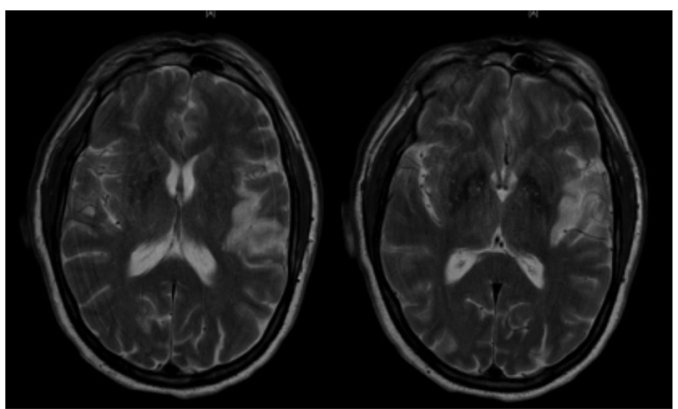

Figure 1 Increased signal intensity seen in the left frontoparietal region on $\mathrm{T} 2$ sequences, consistent with an acute infarct. prevalence of thrombi, with the insertion site, usually a small atherosclerotic plaque, typified by increased mural echo density. ${ }^{1}$ TOE is widely reported as the most sensitive investigation, however, as in our case, TTE may be sufficient. Echocardiography allows assessment of the size, mobility and profile of the insertion site, which can guide treatment. ${ }^{2}$ Optimal treatment has yet to be defined. Definitive treatment may be undertaken via surgical removal, balloon embolectomy and thrombolysis. ${ }^{3}$ Anticoagulation, while removing the surgical risk, may result in recurrent distal embolisation. Close monitoring of international normalised ratio and follow-up TTE or TOE is required; resolution has been documented with thrombi sized $0.5-3 \mathrm{~cm}$.

\section{Learning points}

- In patients with unexplained systemic embolism, aortic arch thrombus must be considered as a potential cause.

- Transthoracic echocardiogram and transoesophageal echocardiogram are important non-invasive tests to identify aortic arch thrombi.

Competing interests None declared.

Patient consent Obtained.

Provenance and peer review Not commissioned; externally pee reviewed. 


\section{REFERENCES}

1 Zarins CK, Giddens DP, Bharadvaj BK, et al. Carotid bifurcation atherosclerosis. Quantitative correlation of plaque localization with flow velocity profiles and wall shear stress. Circ Res 1983;53:502-14.

2 Laperche T, Laurian C, Roudaut R, et al. Mobile thormboses of the aortic arch without aortic debris. A transesophageal echocardiographic finding associated with unexplained arterial embolisation. The Filiale Echocardiographie de la Société Française de Cardiologie. Circulation 1997;96:288-94.

3 Culliford AT, Tunick PA, Katz ES, et al. Initial experience with removal of protruding atheroma from aortic arch: diagnosis by transesophageal echo, operative technique, and follow-up. J Am Coll Cardiol 1993;21(Suppl A): $342 \mathrm{~A}$

Copyright 2015 BMJ Publishing Group. All rights reserved. For permission to reuse any of this content visit http://group.bmj.com/group/rights-licensing/permissions.

BMJ Case Report Fellows may re-use this article for personal use and teaching without any further permission.

Become a Fellow of BMJ Case Reports today and you can:

- Submit as many cases as you like

- Enjoy fast sympathetic peer review and rapid publication of accepted articles

- Access all the published articles

- Re-use any of the published material for personal use and teaching without further permission

For information on Institutional Fellowships contact consortiasales@bmjgroup.com

Visit casereports.bmj.com for more articles like this and to become a Fellow 